\title{
Regional component in the main curriculum of secondary general education
}

\author{
Natalia Nikolaevna Zakirova ${ }^{1}$, Vera Nikolaevna Martyanova, Olga Yuryevna Ovchenkova, \\ Svetlana Leonidovna Skopkareva, and Yanina Alexandrovna Chigovskaya-Nazarova
}

Glazov State Pedagogical Institute named after V.G. Korolenko, Department of Russian Language and Literature, Glazov, Russia

\begin{abstract}
The article is devoted to the development of a programme (built-in module) on literature based on the involvement of a regional component in the content of literary education of students of general education and specialized schools of the Udmurt Republic, as well as other national schools of the Volga region and the Urals. Knowledge of their national literature, literature of neighbouring peoples, and familiarization with the treasury of the spiritual culture of their people contribute to the patriotic education of the younger generation. The content of the module consists of sections devoted to the work of the most significant representatives of the literature of Udmurtia and Russian writers who influenced the formation of the cultural code of the region (V. Korolenko, M. Khudyakov, K. Mitrey, K. Gerd, M. Petrov, G. Krasilnikov, V. Ar-Sergi, V. Vladykin and many others). The programme module can be implemented both within the framework of the work curriculum for literature, and at the profile level in the form of an elective course. In accordance with the requirements of the federal state educational standard of secondary general education the course realizes innovative approaches, such as: system-activity, competence, personality-oriented contributing to the creation of an innovative learning space. Productive techniques and technologies (technologies of thoughtful reading, reading and writing for the development of critical thinking, research and project activities, ICT technologies, etc.), and the widespread use of Internet resources contribute to the formation of both subject and metasubject competencies. In addition to theoretical knowledge, students will acquire and improve practical skills in research, work with various sources, analysis and comparison of various texts including in the national language.

Keywords: patriotic education, regional component, productive methods, innovative approaches, federal state educational standard, basic general education
\end{abstract}

\section{Introduction}

\footnotetext{
${ }^{1}$ Corresponding author: natnik50@rambler.ru
} 
The relevance of the proposed topic is determined by the priority tasks of patriotic education as a condition of national security, which is emphasised in the FSES (Federal State Educational Standard) of the second generation. Consciousness of self as a part of a great people with its unique culture and rich history begins with love for a small homeland, i.e. the place where you were born, went to school and realised yourself as a person. An inexhaustible source of the formation of a child's national self-awareness should be the school, subjects of the humanitarian cycle which shape the worldview of students [1].

At the same time, for all the importance of regional literature, school curricula do not include works of literature of small nationalities of Russia. However, in the school of the national republic, such inclusion is desirable. The regional component can be implemented in the programme of specialised training in literature (elective course) or included as an embedded module in the subject work curriculum.

To effectively implement the course, the teacher must have appropriate training, both on the subject and the methodology. Responding to the challenges of the times, the pedagogical university carries out professional training of the future language and literature teacher on the basis of an integrative approach in which a harmonious combination of pedagogical, psychological, methodological and subject training is necessary for the teacher's personality to become a conductor of the "living word" [2-6].

We will offer the programme of the elective course on Literature of Udmurtia built on the basis of integrative ties between Russian and Udmurt literature.

The purpose of the course: acquaintance with the summit works of Udmurt literature; identification of the influence of Russian literature on its formation and development; identification of the main directions of the study of works in modern regional literary criticism [7-10].

In the process of studying the course, it is necessary to solve the following tasks:

- to create conditions for the formation of a sense of patriotism, love for a small homeland, as well as an awareness of their belonging to the great Russian culture [11-13];

- to study the works of Udmurt literature, to acquaint with the works of literary scholars [14];

- to form design and research competencies in students based on a comparative analysis of works of Russian and Udmurt literature [1, 15]

\section{$2 \quad$ Methods}

Methods of studying the course are productive. Implementing strategic approaches in the conditions of work of the Federal State Educational Standard (system-activity, personality-oriented, competence-based), let us turn to the technologies of design and research activities, methods of creative reading and creation of speech utterance, and technology of creative writing workshops. The dialogue of cultures will find its methodological expression in dialogue technologies [16].

\section{$3 \quad$ Results and discussion}

The course is designed for 36 hours. It can be either an independent course or an embedded module (extracurricular reading lessons). Each topic is given 3 hours: 2 hours for working with various sources (texts, Internet resources), 1 hour for presenting independent work.

Table. The programme of the course on Literature of Udmurtia. 


\begin{tabular}{|c|c|c|c|}
\hline Theme & $\begin{array}{l}\text { Numbe } \\
\text { r of } \\
\text { hours }\end{array}$ & Short contents of the course & Methods \\
\hline $\begin{array}{l}\text { 1. The epos of the } \\
\text { Udmurt people in } \\
\text { literary works } \\
\text { (M. Khudyakov, } \\
\text { K. Gerd, } \\
\text { N. Baiteryakov, } \\
\text { V. Vanyushev). }\end{array}$ & $3(2+1)$ & $\begin{array}{l}\text { For many decades, the interest of } \\
\text { Udmurtian poets in folklore has not } \\
\text { waned. Folk legends are not only a } \\
\text { source of plots, but also a kind of } \\
\text { storehouse of poetics. At the same time, } \\
\text { developing folklore traditions in their } \\
\text { poems, artists are sensitive to the trends } \\
\text { of the times and respond to } \\
\text { contemporary events by addressing the } \\
\text { necessary topics. Poets of Udmurtia, } \\
\text { even when creating epic pictures of the } \\
\text { past, use the methods of psychological } \\
\text { analysis, creation of a psychological } \\
\text { landscape, dramatic saturation and } \\
\text { philosophical aspect. }\end{array}$ & $\begin{array}{l}\text { The teacher's } \\
\text { lecture, problem } \\
\text { discussion on The } \\
\text { Originality of the } \\
\text { Udmurt Epic, } \\
\text { poster presentation } \\
\text { on the work of the } \\
\text { writer (at the } \\
\text { choice of students) }\end{array}$ \\
\hline $\begin{array}{l}\text { The role of } \\
\text { G. Vereshchagin } \\
\text { and V. Korolenko in } \\
\text { the notorious } \\
\text { Multan case (based } \\
\text { on documentary } \\
\text { materials and Old } \\
\text { Multan, the novel } \\
\text { by M. Petrov). }\end{array}$ & $3(2+1)$ & $\begin{array}{l}\text { V.G. Korolenko's political exile to } \\
\text { Glazov. Reflection of Glazov's } \\
\text { impressions in the writer's work. Multan } \\
\text { case (1892-1896) - the trial of a group } \\
\text { of Udmurt peasants from the village of } \\
\text { Stary Multan, Malmyzhsky District, } \\
\text { Vyatka Province. } 10 \text { inhabitants of this } \\
\text { village were unjustly accused of ritual } \\
\text { murder, a human sacrifice to the pagan } \\
\text { gods. It was a typical example of blood } \\
\text { libel. The case received a wide public } \\
\text { response, thanks to which the accused } \\
\text { were acquitted at the third trial in June } \\
1896 \text { in Mamadysh. An important role } \\
\text { in the acquittal of the accused was } \\
\text { played by V.G. Korolenko and G.E. } \\
\text { Vereshchagin, the conclusion given on } \\
\text { the complaint of the defense by A.F. } \\
\text { Koni. Memory of V.G. Korolenko, the } \\
\text { humanist and human rights activist, in } \\
\text { Udmurtia. Korolenko`s movement at the } \\
\text { Glazov Pedagogical Institute. }\end{array}$ & $\begin{array}{l}\text { Group work with } \\
\text { various sources, } \\
\text { creation of Multan } \\
\text { Case in History } \\
\text { and Literature, an } \\
\text { educational } \\
\text { project. }\end{array}$ \\
\hline $\begin{array}{l}\text { 3. F. Dostoevsky's } \\
\text { traditions in } \\
\text { K. Mitrei`s works }\end{array}$ & $3(2+1)$ & $\begin{array}{l}\text { For Dostoevsky's prose, heightened } \\
\text { attention to crisis conditions in the } \\
\text { development of society and the } \\
\text { individual is characteristic. Social } \\
\text { circumstances that divide people and } \\
\text { generate evil in their souls, push heroes } \\
\text { onto the path of resistance, give rise to } \\
\text { their desire to comprehend the } \\
\text { contradictions of the era, and awaken } \\
\text { both reason and conscience. Hence the } \\
\text { saturation of Dostoevsky's novels with } \\
\text { philosophical thought, acute attention to } \\
\text { the inner world of man. Following } \\
\text { Dostoevsky, K. Mitrey, in his story } \\
\text { "Child of a Sick Age", turns to the } \\
\text { artistic reproduction of the process of }\end{array}$ & $\begin{array}{l}\text { The teacher's } \\
\text { lecture, group (or } \\
\text { pair) work with } \\
\text { texts on the } \\
\text { comparative } \\
\text { analysis of the } \\
\text { works of F.M. } \\
\text { Dostoevsky and K. } \\
\text { Mitrey. } \\
\text { Presentation of } \\
\text { research results. }\end{array}$ \\
\hline
\end{tabular}




\begin{tabular}{|c|c|c|c|}
\hline & & $\begin{array}{l}\text { spiritual searches and self-education of a } \\
\text { young man. }\end{array}$ & \\
\hline $\begin{array}{l}\text { 4. N. Nekrasov`s } \\
\text { traditions in } \\
\text { M. Petrov`s poetry. }\end{array}$ & $3(2+1)$ & $\begin{array}{l}\text { Nekrasov's motives can be traced in M. } \\
\text { Petrov's appeal to reflections on the } \\
\text { influence of childhood impressions on } \\
\text { the life and creative path of a person, in } \\
\text { the construction of an antithesis: } \\
\text { beautiful, harmonious nature sharply } \\
\text { contrasts with the "ugliness" of human } \\
\text { relations. Following N.A. Nekrasov } \\
\text { M.P. Petrov, personifying the world } \\
\text { around him, speaks of his empathy for } \\
\text { human grief. }\end{array}$ & $\begin{array}{l}\text { The teacher's } \\
\text { lecture, group } \\
\text { research on the } \\
\text { "Contrast as an } \\
\text { Artistic Principle } \\
\text { of N. Nekrasov } \\
\text { and M. Petrov's } \\
\text { Poetics. } \\
\text { Presentation of } \\
\text { research results. }\end{array}$ \\
\hline $\begin{array}{l}\text { 5. The image of } \\
\text { modernity in } \\
\text { G. Krasilnikov's } \\
\text { story "I Stay with } \\
\text { You" }\end{array}$ & $3(2+1)$ & $\begin{array}{l}\text { The genre nature of G. Krasilnikov's } \\
\text { story, built as a hero's confession, helps } \\
\text { the reader to enter the artistic space of } \\
\text { the work, to relate his life to the fate of } \\
\text { the character. Such techniques as the } \\
\text { hero's introspection of his own thoughts } \\
\text { and feelings, the study of human nature } \\
\text { in general and human relationships in } \\
\text { particular, a detailed portrait and the use } \\
\text { of various types of landscape (social, } \\
\text { psychological, philosophical) for a more } \\
\text { complete disclosure of the character of } \\
\text { the hero - all of this is subordinated by } \\
\text { the writer to a single goal: creating the } \\
\text { image of a young contemporary, } \\
\text { growing up in life's trials building his } \\
\text { life according to the laws of conscience } \\
\text { and human morality, is necessary for an } \\
\text { artist to designate his own philosophical } \\
\text { and aesthetic concept of a person - a } \\
\text { doer and thinker. }\end{array}$ & $\begin{array}{l}\text { The teacher's } \\
\text { lecture, creation of } \\
\text { an educational } \\
\text { project } \\
\text { "Peculiarities of } \\
\text { G. Krasilnikov's } \\
\text { Psychologism". } \\
\text { Project protection. }\end{array}$ \\
\hline $\begin{array}{l}\text { 6. Moral problems } \\
\text { in } \quad \text { V. Ar-Sergi`s } \\
\text { works }\end{array}$ & $3(2+1)$ & $\begin{array}{l}\text { The hero of Ar-Sergi's works lives } \\
\text { today, but, at the same time, belongs to } \\
\text { eternity, holds the whole Universe in his } \\
\text { heart and understands all the conquests } \\
\text { of civilisation. We see a portrait of a } \\
\text { MAN who can be always and } \\
\text { everywhere, connected by many threads } \\
\text { with the past and future, living in } \\
\text { constant communication with the world } \\
\text { of departed ancestors, pagan gods and } \\
\text { spirits, eternally living nature, with the } \\
\text { most distant point of the Universe, with } \\
\text { the closest people and with himself. } \\
\text { This portrait reveals the poet's } \\
\text { postmodern vision of human nature, } \\
\text { human life as simultaneity, } \\
\text { one-existence, and the possibility of the } \\
\text { existence of everything always in } \\
\text { everything. }\end{array}$ & $\begin{array}{l}\text { Organisation of } \\
\text { research work } \\
\text { "Human nature in } \\
\text { the image of } \\
\text { V. Ar-Sergi" (work } \\
\text { with text, } \\
\text { reference materials } \\
\text { and Internet } \\
\text { resources). } \\
\text { Presentation of } \\
\text { results. }\end{array}$ \\
\hline $\begin{array}{l}\text { 7. K. Gerd, a poet, a } \\
\text { philologist, an }\end{array}$ & $3(2+1)$ & $\begin{array}{l}\text { Over the Shoshma and Keremet, } \\
\text { K. Gerd`s early poems, are } \\
\text { distinguished by symbolism, romantic }\end{array}$ & $\begin{array}{l}\text { Drawing up a } \\
\text { reference outline. } \\
\text { Problematic }\end{array}$ \\
\hline
\end{tabular}




\begin{tabular}{|c|c|c|c|}
\hline $\begin{array}{l}\text { ethnographer, } \\
\text { culturologist }\end{array}$ & & $\begin{array}{l}\text { techniques, and philosophicality. The } \\
\text { Tsar's War, Rebel Onton, narrative } \\
\text { poems, contain psychologically rich } \\
\text { sketches of the heroes' lives. Snowstorm } \\
\text { in the Village, Ten Years, lyrical and } \\
\text { publicistic poems, express the author's } \\
\text { attitude to events taking place in public } \\
\text { life. My Death, a lyric-meditative poem, } \\
\text { is the author's reflections on the } \\
\text { pressing problems of both personal and } \\
\text { social life. And, finally, Blue Smoke, a } \\
\text { lyric and psychological poem, depicts } \\
\text { the subtlest shades of the psyche of the } \\
\text { lyrical hero of the work. }\end{array}$ & $\begin{array}{l}\text { discussion on } \\
\text { Features of the } \\
\text { Genre of the Poem } \\
\text { in K. Gerd's work } \\
\text { according to the } \\
\text { teacher's } \\
\text { questionnaire. }\end{array}$ \\
\hline $\begin{array}{l}\text { 8. V. Vladykin, a } \\
\text { scientist and a poet }\end{array}$ & $3(2+1)$ & $\begin{array}{l}\text { V.E. Vladykin is not only a lyricist, but } \\
\text { a well-known ethnographer, Doctor of } \\
\text { Historical Sciences, Professor of UdSU, } \\
\text { Honorary Foreign Member of the } \\
\text { Ethnographic Society of the Hungarian } \\
\text { Academy of Sciences, Honorary } \\
\text { Foreign Member of the Finno-Ugric } \\
\text { Society (Finland), Honorary Foreign } \\
\text { Member of the Finnish Literary Society } \\
\text { (Finland), and Member of the Writers' } \\
\text { Union of Russia. } \\
\text { In one of his interviews, the poet } \\
\text { explains the combination in his activity } \\
\text { of such seemingly diverse phenomena } \\
\text { as science and lyrics: "While studying at } \\
\text { Moscow University, I ... gradually came } \\
\text { to ethnography ... My hobbies for } \\
\text { literature, art, music were realised in this } \\
\text { science because in ethnography, it seems } \\
\text { to me, all this can be combined together. } \\
\text { The people is a capacious concept, it } \\
\text { combines the problems of literature } \\
\text { through folklore, and art through the } \\
\text { system of folk aesthetic values, and a } \\
\text { number of philosophical aspects ... after } \\
\text { all, through your people you learn about } \\
\text { all of humanity ..." }\end{array}$ & $\begin{array}{l}\text { Creation and } \\
\text { presentation of the } \\
\text { Formation of the } \\
\text { Scientist and Poet } \\
\text { V. Vladykin, a } \\
\text { collective project. } \\
\text { Creation of a } \\
\text { bibliographic list } \\
\text { of the scientist's } \\
\text { works. }\end{array}$ \\
\hline $\begin{array}{l}\text { 9. V. Vanyushev, a } \\
\text { poet, an } \\
\text { ethnographer, a } \\
\text { philologist, } \\
\text { historian. }\end{array}$ & $3(2+1)$ & $\begin{array}{l}\text { V.M. Vanyushev's Udmurt Vyzhy Kniga } \\
\text { (On Idnakar), a poem, is a kind of } \\
\text { culmination in the poet's work. The } \\
\text { work opened a new page in the history } \\
\text { of the folk-epic poem of Udmurtia. It } \\
\text { attracts attention not only with a modern } \\
\text { reading of the history of the people or } \\
\text { the poet's ability to combine epic and } \\
\text { lyric poetry. The complex, mosaic } \\
\text { structure of the poem is of interest } \\
\text { which allows the author to present the } \\
\text { subject of his artistic research in a } \\
\text { multifaceted manner: prosaic and poetic } \\
\text { fragments, complementing and } \\
\text { deepening each other, are combined into }\end{array}$ & $\begin{array}{l}\text { Research work on } \\
\text { V. Vanyushev's } \\
\text { work. Preparation } \\
\text { of a speech at the } \\
\text { school scientific } \\
\text { and practical } \\
\text { conference. } \\
\text { Writing a } \\
\text { scientific article. }\end{array}$ \\
\hline
\end{tabular}




\begin{tabular}{|c|c|c|c|}
\hline & & $\begin{array}{l}\text { a single lyric-epic canvas and a } \\
\text { lyric-philosophical poem. }\end{array}$ & \\
\hline $\begin{array}{l}\text { 10. The image of } \\
\text { mother nature in } \\
\text { F. Vasiliev's lyrics. }\end{array}$ & $3(2+1)$ & $\begin{array}{l}\text { In F. Vasiliev`s lyrics, man is a part of } \\
\text { nature, a part of a common indivisible } \\
\text { whole... F. Vasiliev's hero is an Udmurt } \\
\text { who loves his land, feels it, knows } \\
\text { where the forest path leads, how pine } \\
\text { needles and buckwheat smells, what a } \\
\text { lark and the quiet wind sings about from } \\
\text { the river. All these details that fill the } \\
\text { poet's poems are combined into a } \\
\text { full-blooded, all-encompassing image of } \\
\text { his native land without which the lyrical } \\
\text { hero cannot be aware of oneself as a } \\
\text { human. }\end{array}$ & $\begin{array}{l}\text { The teacher's } \\
\text { mini-lecture, } \\
\text { Distance excursion } \\
\text { to memorial sites. } \\
\text { Creation of a } \\
\text { media product. } \\
\text { Presentation and } \\
\text { protection of the } \\
\text { project. }\end{array}$ \\
\hline $\begin{array}{l}\text { 11. Methods of } \\
\text { depicting time and } \\
\text { man in } \\
\text { O. Poskrebyshev's } \\
\text { poetry. }\end{array}$ & $3(2+1)$ & $\begin{array}{l}\text { One of the characteristic features of O. } \\
\text { Poskrebyshev's poetry is drama. Such } \\
\text { emotional richness of works leads the } \\
\text { author to the use of special artistic } \\
\text { means. This is, first of all, the dynamism } \\
\text { of the lyrical plot, which can, in } \\
\text { particular, be achieved through a kind of } \\
\text { "breaks" between parts of the work. } \\
\text { Such "gaps" replace the talking dots, are } \\
\text { a plot ellipse that not only does not } \\
\text { separate the parts of the artistic whole, } \\
\text { but allows each of them, remaining a } \\
\text { bright, self-sufficient detail in its own } \\
\text { way, to fall right into place in a } \\
\text { complete, multicoloured mosaic. }\end{array}$ & $\begin{array}{l}\text { The teacher's } \\
\text { mini-lecture. } \\
\text { Analysis } \\
\text { poems, } \\
\text { comparison with } \\
\text { the works of } \\
\text { Russian and } \\
\text { Udmurt lyrics. } \\
\text { "What is close to } \\
\text { me in } \\
\text { O. Poskrebyshev's } \\
\text { poetry", an essay. } \\
\text { Illustrating. } \\
\text { Preparation and } \\
\text { presentation of the } \\
\text { project. }\end{array}$ \\
\hline $\begin{array}{l}\text { 12. V. Semakin as } \\
\text { one of the galaxy of } \\
\text { Russian poets of the } \\
\text { Udmurt land. }\end{array}$ & $3(2+1)$ & $\begin{array}{l}\text { V.K. Semakin was born in Glazov. After } \\
\text { graduating from the Literary Institute } \\
\text { named after M. Gorky he worked in the } \\
\text { Soviet Writer Moscow Publishing } \\
\text { House as editor-in-chief for thirty years } \\
\text { and as head of the editorial board of } \\
\text { Russian Soviet poetry for the last seven } \\
\text { years. For many years Vladimir } \\
\text { Kuzmich was not only engaged in his } \\
\text { own work, but also translated the poems } \\
\text { of the Udmurt poets, helped them } \\
\text { publish books in the capital, and } \\
\text { introduced them to other translators. V. } \\
\text { Semakin can rightfully be called an } \\
\text { ambassador of Udmurt literature in } \\
\text { Moscow. }\end{array}$ & $\begin{array}{l}\text { Poetic party } \\
\text { dedicated to } \\
\text { V. Semakin's } \\
\text { poetry. Reading } \\
\text { and analysis of } \\
\text { works. }\end{array}$ \\
\hline
\end{tabular}

The result of studying the course will be the formation of cognitive competencies (work with various sources of information, structuring information), regulatory (setting a goal and choosing a way to achieve it, reflection), communicative (cooperation in a group, in a pair). Subject and metasubject competencies are formed in the process of familiarisation with the spiritual treasury of Russian and national literature. 


\section{Conclusion}

The need to include the regional component in the content of education is dictated by the understanding of the importance of the didactic potential of national literature in the matter of patriotic education. The proposed content, technologies and methodology for implementing the course based on innovative approaches in the conditions of FSES BGE are aimed at the implementation of the ethnocultural component as an obligatory component of the educational process that contributes to the development of the individual in a multicultural educational space. Knowledge of literature, history, language of their people, understanding of the fruitful mutual influence of Russian and national literature will allow students to socialise and perceive the spiritual values of the titular nation of Udmurtia as part of the great Russian culture.

\section{References}

1. L.A. Bogdanova, O.Yu. Ovchenkova, Tvorcheskoe nasledie G.E. Vereshchagina kak material dlya samostoyatelnogo issledovaniya shkolnika [The creative heritage of G.E. Vereshchagin as a material for an independent study of a schoolchild], in S.B. Kurash (ed.), Text. Language. Man: Collection of research papers in two parts, part 1, 90-93 (Mozyr, 2017)

2. E.O. Galitskikh, Continuous Edu. 1(23), 51-54 (2018)

3. E.O. Galitskikh, Pedag. IMAGE 13(2), 213-226 (2019). https://doi.org/10.32343/2409-5052-2019-13-2-63-76

4. M.G. Sergeeva, et al., Espacios, 39(38), 4 (2018)

5. E.P. Morozova, et al., Opcion, 34(85), 1878-1890 (2018)

6. Y.A. Chigovskaya-Nazarova, Pedag. Edu. Rus. 1, 17-21 (2018)

7. N.N. Zakirova, Yearbook of Finno-Ugric Stud. 11(2), 187-190 (2017)

8. N.N. Zakirova, O.Yu. Ovchenkova, Sci. Udmurtia 3(61), 21-28 (2012)

9. N.N. Zakirova, Y.A. Chigovskaya-Nazarova, Kazan Sci. 5, 115-117 (2014)

10. N. Zakirova, L. Olkhovskaya, M. Konliff, Bul. Slavic Cult. 2(48), 92-100 (2018)

11. V.N. Martyanova, N.N. Zakirova, Kontsept provintsii v yazykovom soznanii Korolenko [The concept of a province in the linguistic consciousness of Korolenko], in Linguistics and its place in the interdisciplinary scientific space: Materials of the All-Russian scientific conference with international participation, 119-122 (Kirov, 2008)

12. S.L. Skopkareva, O mezhkulturnom vzaimodeistvii Ukrainy i Rossii: $k$ voprosu ob izuchenii zhizni i tvorchestva $V$. G. Korolenko [On intercultural interaction between Ukraine and Russia: on the study of the life and work of V.G. Korolenko], in O.A. Kravchenko, N.E. Kaika (eds.), Culture in the focus of scientific paradigms, Materials of the IV International Scientific and Practical Conference, Donetsk, April 6-7, 2016, Issue. 4, 141-142 (Donetsk, 2016)

13. S.L. Skopkareva, Literary Criticism, 7, 137-141 (2017)

14. L.A. Bogdanova, Kontseptosfera povesti G.D. Krasilnikova "Ostayus s toboi” [The conceptual sphere of G.D. Krasilnikov's story "I Stay with You”], in A.E. Zagrebin 
(ed.), Yearbook of Finno-Ugric Studies. Issue 4 (Udmurt University Publishing House, Izhevsk, 2013)

15. A. Gazizova, M. Siraeva, V. Panfilova, S. Skopkareva, Modelling of the humanitarian learning environment within Russian universities on the basis of non-formal education, in Proc. 15th International Technology, Education and Development Conference INTED 2021, 8-9 March, 2021. https://doi.org/10.21125/inted.2021.0498

16. E. Galitskih, et al., Espacios, 39(40), 24 (2018) 